\title{
The Effects of Pine Tree Sawdust on the Volume Compressibility of Expansive Soils
}

\author{
Ekrem Kalkan \\ Department of Civil Engineering \\ Engineering Faculty \\ Ataturk University \\ Erzurum, Turkey
}

\author{
Necmi Yarbaşı \\ Department of Civil Engineering \\ Engineering Faculty \\ Ataturk University \\ Erzurum, Turkey
}

\begin{abstract}
Expansive soils are very important natural geological materials used in the geotechnical applications in the worldwide. After compacting, they are used as hydraulic barriers in earth structures, such as core of earth fill dams, landfill liners, and etc. However, these soils have some defects from technical points of view. To remove the defects, one of the soil improvement methods is mixing of these soils with granular materials. In this study, pine tree sawdust was used as granular additive material to stabilize the expansive soils. The effects of pine saw dust on the volume compressibility of expansive soils were investigated by using experimental studies under laboratory conditions. The test results showed that the pine saw dust positively affected the geotechnical properties in term of volume compressibility manner. As a consequently, the geotechnical properties of the expansive soil when blended with pine tree sawdust indicates that the pine tree sawdust is a good modification material for this problematic soil.
\end{abstract}

Keywords: Expansive soil, waste material, pine tree sawdust, soil stabilization, volume compressibility

\section{INTRODUCTION}

The soil is one of the oldest and perhaps most complex geological materials that humanity has been working on. Various problems have begun to be encountered by using the expansive soil as foundation or material. The expansive soil changes in volume in relation to changes in water content. This occurs as swelling upon wetting, and shrinkage upon drying. These soils have poor volume stability in the presence of water (Jones and Jefferson, 2012; Li et al., 2014; Khanduri, 2020). These soils have a problem worldwide undergoing considerable volume changes such as swelling on absorbing water and shrinking on evaporation.

Moreover, moisture fluctuations of them cause distinct changes in soil strength (Fredlund and Rahardjo, 1993; Sheng et al., 2008; Phanikumar, 2009; Lin, and Cerato, 2012; Poonia et al., 2019). Such soils should generally be avoided for the purpose of construction. Because, the structural damages of constructures built on expansive soils is well documented in literature (Petry and Little, 2002; Fall and Sarr, 2007; Kalkan and Bayraktutan, 2008; Ozer et al., 2011; Jones and Jefferson, 2012; Tiwari et al., 2012; Kalkan et al., 2019; James, 2020; Kalkan et al., 2020; Yarbaşı and Kalkan, 2020a). Also, the damage to lightly loaded structures founded on expansive soils has been widely reported (Cameron et al., 1987; Walsh and Cameron, 1997; Fityus et al., 2004; Delaney et al., 2005; Miao et al., 2012; Li et al., 2014; Kalkan et al., 2015).

The soil is one of the most important and primary media for any construction work. The strength and durability of any structure depends on the strength properties of soil (Nath et al., 2017). Soil stabilization is defined as a technique to improve the engineering characteristics in order to improve the parameters such as shear strength, compressibility, density, hydraulic conductivity. The techniques of soil stabilization can be classified into a number of categories such as vibration, surcharge load, structural reinforcement improvement by structural fill, admixtures, and grouting and other methods. There are many techniques that can be used for different purposes by enhancing some aspects of soil behavior and improve the strength and properties of soil (Edil, 2003; Kazemain and Barghchi, 2012).

In some geotechnical engineering projects, such as core of earth fill dams, landfill liners, and etc, to achieve lower values of hydraulic conductivity it requires to compact clayey soils at wet of optimum water content. Shear strength of clayey soils in general is relatively low and when they subject to seasonal drying, loss of water occurs due to desiccation that alters their properties, including reduction in soil plasticity, possible cracking, and increasing of hydraulic conductivity (SoltaniJigheh and Jafari, 2012).

Expansive soils pose the problem of swelling on absorption of water during monsoon and shrinkage on evaporation of water in summer (Chen, 1988, McKeen 1988; Nelson and Miller, 1992; Kenneth, 1993). As a result of the swell-shrink behavior of expansive soils, lightly loaded structures such as foundations, pavements, canal beds, and linings and residential buildings founded in them are severely damaged (Chen, 1988).

The several researchers have investigated the effect of granular material on the mechanical properties of mixed clayey soils (Holtz and Willard, 1956; Nakase et al., 1978; Shakoor and Cook, 1990; Shelley and Daniel, 1993; Howell et al., 1997). Vallejo and Mawby (2000) carried out direct shear tests on mixtures of Ottawa sand-kaolin clay and found that shear strength of the mixtures depends upon their sand contents (Soltani-Jigheh and Jafari, 2012).

Several soil stabilization methods are available for stabilization of expansive clayey soils. These methods include the use of chemical additives, rewetting, soil replacement, compaction control, moisture control, surcharge loading, and thermal methods (Chen, 1988; Nelson and Miller, 1992; Yong and Ouhadi, 2007). Many investigators have studied natural, fabricated, and by-product materials and their use as additives for the stabilization of clayey soils (Kalkan, 2020; Kalkan and Yarbaşı, 2020; Kalkan et al., 2020; Yarbaş1 and Kalkan, 2020a; Yarbaş1 and Kalkan, 2020b; Yarbaşı and Kalkan, 2020c). 
Soil stabilization is one of the most widely followed techniques to control the swelling behavior of expansive soils in lightly loaded structures (Selvakumar and Soundara, 2019). The stabilization techniques to control the swelling characteristics in expansive soils can be grouped into mechanical, chemical and polymer as well as unconventional stabilizer methods (Petry and Little, 2002; Ikizler et al., 2009; Estabragh et al., 2014; Kalkan et al., 2019; Kalkan, 2020; Yarbaş1 and Kalkan, 2020a). In the chemical stabilization, some additives such as lime, cement, fly ash, silica fume etc., are added, which physically interacts with the soil and change the index properties (Chen, 1988; Çokça, 2001; Kalkan and Akbulut, 2004; Kalkan, 2009; Kalkan, 2011; Jamsawang et al., 2017; Chittoori et al., 2018; Kalkan et al., 2019). In recent times, the use of polymer-based product such as geosynthetics in expansive soil stabilization (Al-Omari and Hamodi, 1991; Sharma and Phanikumar, 2005; Viswanadham et al., 2009; Buzzi et al., 2010) is widely practiced due to their desirable properties and durability (Jewell, 1991; Koerner, 1999; Selvakumar and Soundara, 2019).

In this study, the pine tree sawdust was used as alternative low-cost stabilizer material. The main objectives of this research are to investigate the utilizable of pine tree sawdust as additive material for stabilization of expansive soils in geotechnical applications in term of volume compressibility manner. The stabilized expansive soils were subjected the consolidation tests and the results obtained were compared with that of natural expansive soils

\section{MATERILA and METHODS}

\subsection{Materials}

The expansive soil material was supplied from the clayey soil deposits of Oltu-Narman sedimentary basin, Erzurum, NE Turkey. The expansive soil samples were taken $0,75 \mathrm{~m}$ deep. According to the United Soil Classification System, expansive soil are inorganic clays of high plasticity $(\mathrm{CH})$. These soils have high expansion potential as a result of over consolidation, high-very high plasticity and montmorillonite content (Kalkan, 2003; Kalkan and Bayraktutan, 2008). The grain-size distribution of expansive soil was given in Figure 1.

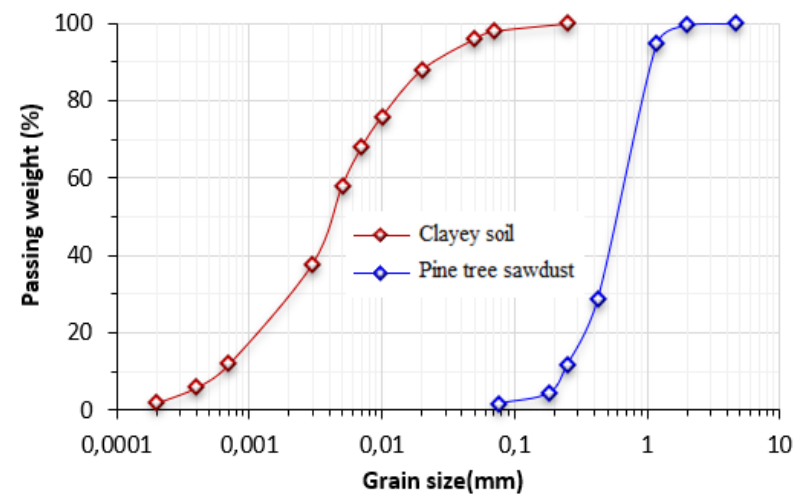

Figure 1. Grain size distribution of expansive soil and pine tree sawdust

Wood cutting factories, generates a by-product known as sawdust. The pine tree sawdust waste material was obtained from the carpenters in the industrial zone of Oltu (Erzurum), NE Turkey. The pine tree sawdust is an organic waste resulting from the mechanical milling or processing of timber (wood) into various standard shapes and useable sizes. Consisting of soil-like particulate materials that are lighter than soil, sawdust inexpensive and environmentally safe (Rao et al., 2012; Oyedepo et al., 2014). The grain-size distribution of pine tree sawdust was illustrated in the Figure 1.

\subsection{Methods}

\subsubsection{Preparation of samples}

Before preparation of samples, the expansive soil and pine tree sawdust materials were mixed at the different contents of them. Under dry condition, expansive soil and pine tree sawdust materials were mixed to prepare mixtures of expansive soil-pine tree sawdust. The amounts of pine tree sawdust were selected to be $0,5 \%, 1 \%$ and $1,5 \%$ of the total dry weight of the mixtures (Table 1). The dry mixtures were mixed with the required amount of water recognized to give the optimum water content. All mixing was done manually and proper care was taken to prepare homogeneous mixtures at each stage.

Table 1. The expansive soil and pine tree rates of mixtures

\begin{tabular}{cccc}
\hline Samples & $\begin{array}{c}\text { Expansive soil } \\
(\boldsymbol{\%})\end{array}$ & $\begin{array}{c}\text { Pine tree sawdust } \\
(\boldsymbol{\%})\end{array}$ & $\begin{array}{c}\text { Total } \\
(\boldsymbol{\%})\end{array}$ \\
\hline MIX0 & 100 & - & 100 \\
MIX1 & 99,5 & 0,5 & 100 \\
MIX2 & 99,0 & 1,0 & 100 \\
MIX3 & 98,5 & 1,5 & 100 \\
\hline
\end{tabular}

\subsubsection{Standard odometer test}

The compressibility behaviors of expansive soil and expansive soil-pine tree sawdust mixtures were assessed from standard odometer tests. The standard oedometer test is a classical laboratory test that allows characterizing the soil stress-strain behavior during one-dimensional compression or swelling. The samples compacted at their optimum moisture content in a standard proctor mold and then extruded using a cutting ring were subjected to one dimensional consolidation tests in accordance with ASTM D 2435.

\section{Results and Discussion}

\subsection{Effects of pine tree sawdust on the coefficient of volume compressibility}

The effects of pine tree sawdust on the coefficient of volume compressibility (mv) of pine tree sawdust-modified expansive soil were illustrated in Figure 2. The mv of pine tree sawdustmodified expansive soil samples significantly increased with addition of more pine tree sawdust content up to $0,5 \%, 1 \%$ and $1,5 \%$. Contrary to this situation, the consolidation coefficient (cv) increases (Figure 3). These mv and cv value were varied at the same consolidation pressure and its might be due to content of clay mineral in the pine tree sawdustmodified expansive soil (Shirazi et al., 2010). The decrease in the void ratio and compressibility of pine tree sawdustmodified expansive soil samples was attributed to the addition of low plastic material and the interaction between clayey minerals and pine tree sawdust particles (Kalkan and Akbulut, 2004). A large number of researchers studied the effect of mineral composition on the compressibility and swelling behavior of expansive soil (Mesri and Olson, 1971; Mitchell, 1993; Di Maio et al., 2004).

\subsection{Image Study}

Figures $4 \mathrm{a}$ and $4 \mathrm{~b}$ show SEM micrographs of natural expansive soil and $0,5 \%$ pine tree sawdust-modified 
expansive soil samples, respectively. It is seen from the images that the addition of pine tree sawdust to the expansive soil caused the structural change pine tree sawdust-modified expansive soil samples. Silt and clay grains of expansive soil showed angular or subangular shapes (Figure 4a).

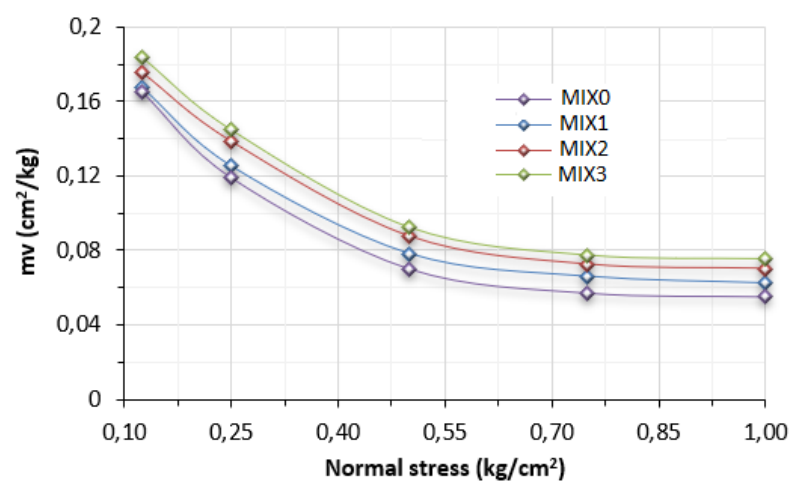

Figure 2. The change in the volumetric compression coefficients of samples

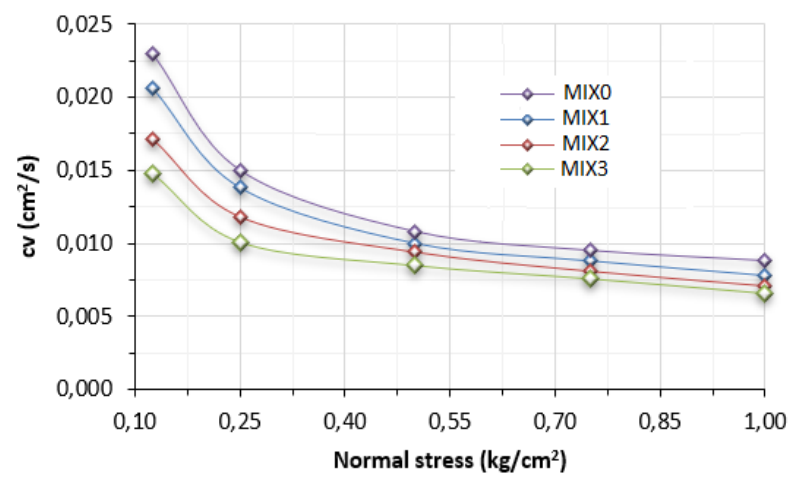

Figure 3. The change in consolidation coefficients of samples

In the $0,5 \%$ pine tree sawdust stabilized samples (MIX1), all grains were covered by relatively thick pine tree sawdust material, which formed cementing medium. This textural event caused a significant improvement in the geotechnical properties. A detailed examination of each micrograph reveals that most of the flocculation products are deposited on the surfaces of the soil grains or at the contact points (Fig. 4b). The bonding of particles into larger aggregates such that the soil behaved as a fine-grained, strongly bonded particulate material (Okyay and Dias, 2010).
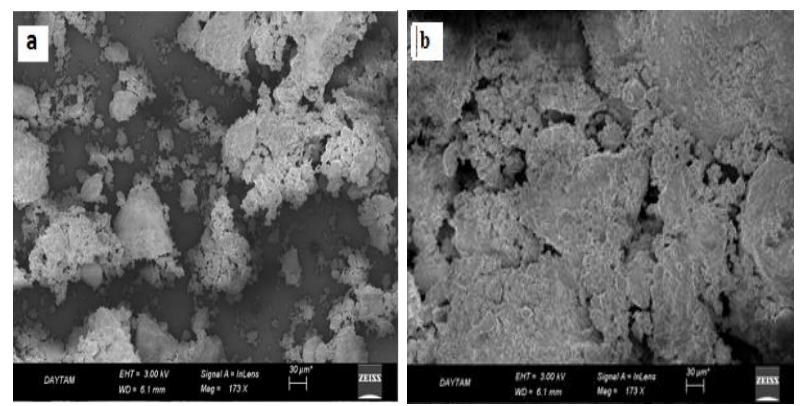

Figure 4. The SEM images of MIX0 and MIX1

\section{CONCLUSIONS}

In this study, the effects of pine tree sawdust on the compressibility behavior of expansive soils. According to the test results, additive of pine tree sawdust improved the compressibility behavior of expansive soil samples. As a result, the pine tree sawdust can be used as an additive material for the stabilization of the expansive soils in the geotechnical applications in term of the compressibility behavior of expansive soils.

\section{REFERENCES}

[1] Al-Omari, R.R., Hamodi, F.J., 1991. Swelling resistant geogrid-a new approach for the treatment of expansive soils. Geotextiles and Geomembranes 10, 295-317.

[2] Buzzi, O., Fityus, S., Sloan, S.W., 2010. Use of expanding polyurethane resin to remediate expansive soil foundations. Canadian Geotechnical Journal 47 (6), 623 634.

[3] Cameron, D.A., Walsh, P.F., Richards, B.G., 1987. Australian approach to the problem of expansive soils. In: Proccedings of 9th Regional Conference for Africa on Soil Mechanics and Foundation Engineering, Lagos, p. 977-989.

[4] Chen, F.H., 1988. Foundations on Expansive Soils. Elsevier Science Publishing Company, Amsterdam.

[5] Chittoori, B.C., Mishra, D., Islam, K.M., 2018. Forensic investigations into recurrent pavement heave from underlying expansive soil deposits. Transportation Research Record Journal of the Transportation Research Board, 0361198118758625.

[6] Çokça, E., 2001. Use of class C fly ashes for the stabilization of an expansive soil. Journal of Geotechnical and Geoenvironmental Engineering 127 (7), 568-573.

[7] Delaney, M.G., Li, J., Fityus, S.G., 2005. Field monitoring of expansive soil behavior in the Newcastlehunter region. Australian Geomechanics Journal, 6 (2), 3-14.

[8] Di Maio, C., Santoli, L., Schiavone, P., 2004. Volume change behaviour of clays: the influence of mineral composition, pore fluid composition and stress state. Mechanics of Materials 36, 435-451.

[9] Edil, T.B., 2003. Recent advances in geotechnical characterization and construction over peat and organic soils" Proceeding's $2^{\text {nd }}$ International Conference on Advances in Soft Soil Engineering and Technology. (Eds). Huat et al. Malaysia: Putrajaya, pp. 3-25.

[10] Estabragh, A.R., Rafatjo, H., Javadi, A.A., 2014. Treatment of an expansive soil by mechanical and chemical techniques. Geosynthetics International 21 (3), 233-243.

[11] Fall, M., Sarr, A.M., 2007. Geotechnical characterization of expansive soils and their implications in ground movements in Dakar. Bulletin of Engineering Geology and the Environment 66 (3), 279-288.

[12] Fityus, S.G., Smith, D.W., Allman, M.A., 2004. An expansive soil test site near Newcastle. ASCE Journal of Geotechnical and Geoenvironmental Engineering 130 (7), 686-695.

[13] Fredlund, D.G., Rahardjo, H., 1993. Soil mechanics for unsaturated soils. United States of America: John Wiley \& Sons.

[14] Holtz, W.G., Willard, M., 1956. Triaxial shear characteristics of clayey gravel soils. Soil Mechanics and Foundation Engineering 82, 143-149. 
[15] Howell, J.L., Shackelford, C.D., Amer, N.H., Stern, R.T., 1997. Compaction of sand processed clay soil mixtures. Geotechnical Testing Journal 20 (4), 443-458.

[16] Ikizler, S.B., Aytekin, M., Vekli, M., 2009. Reductions in swelling pressure of expansive soil stabilized using EPS geofoam and sand. Geosynthetics International 16 (3), 216-221.

[17] James, J., 2020. Sugarcane press mud modification of expansive soil stabilized at optimum lime content: Strength, mineralogy and microstructural investigation. Journal of Rock Mechanics and Geotechnical Engineering 12, 395-402.

[18] Jamsawang, P., Nuansrithong, N., Voottipruex, P., Songpiriyakij, S., Jongpradist, P., 2017. Laboratory investigations on the swelling behavior of composite expansive clays stabilized with shallow and deep claycement mixing methods. Applied Clay Sciences 148, 8394.

[19] Jewell, R.A., 1991. Application of revised design charts for steep reinforced slopes. Geotextile and Geomembranes 10 (3), 203-233.

[20] Kalkan, E., 2003. The improvement of geotechnical properties of Oltu (Erzurum) clayey deposits for using them as barriers. PhD Thesis (in Turkish), Ataturk University, Graduate School of Natural and Applied Science, Erzurum, Turkey.

[21] Kalkan, E., 2009. Influence of silica fume on the desiccation cracks of compacted clayey soils. Applied Clay Science 43, 296-302.

[22] Kalkan, E., 2011. Impact of wetting-drying cycles on swelling behavior of clayey soils modified by silica fume. Applied Clay Science 52, 345-352.

[23] Kalkan, E., 2020. A Review on the Microbial Induced Carbonate Precipitation (MICP) for Soil Stabilization. International Journal of Earth Sciences Knowledge and Applications 2 (1), 38-47.

[24] Kalkan, E., Akbulut, S., 2004. The positive effects of silica fume on the permeability, swelling pressure and compressive strength of natural clay liners. Engineering Geology 73, 145-156.

[25] Kalkan, E., Bayraktutan, M.S., 2008. Geotechnical evaluation of Turkish clay deposits: a case study in Northern Turkey. Environmental Geology 55, 937-950.

[26] Kalkan, E., Nadaroglu, H., Celebi, N., Celik, H., Tasgin, E., 2015. Experimental Study to Remediate Acid Fuchsin Dye Using Laccase-Modified Zeolite from Aqueous Solutions. Polish Journal of Environmental Studies 24 (1), 115-124.

[27] Kalkan, E., Yarbaşı, N., 2020. The effect of waste material mixtures on the mechanical properties of clayey soils. International Journal of Latest Technology in Engineering, Management and Applied Science (IJLTEMAS) 11 (10), 48-52.

[28] Kalkan, E., Yarbasi, N., Bilici, O., 2019. Strength performance of stabilized clayey soils with quartzite material. International Journal of Earth Sciences Knowledge and Applications 1 (1)1-5.

[29] Kalkan, E., Yarbasi, N., Bilici, O., 2020. The Effects of Quartzite on the Swelling Behaviors of Compacted Clayey Soils. International Journal of Earth Sciences Knowledge and Applications 2 (2), 92-101.

[30] Kazemain, S., Barghchi, M., 2012. Review of soft soils stabilization by grouting and injection methods with different chemical binders. Scientific Research and Essays 7 (24), 2104-2111.

[31] Kenneth, D., 1993. Evaluation of In-Place Wetting Using Soil Suction Measurements. Journal of Geotechnical
Engineering, ASCE, 119 (5), 862-873.

[32] Khanduri, S., 2020. Cloudbursts Over Indian Subcontinent of Uttarakhand Himalaya: A Traditional Habitation Input from Bansoli, District-Chamoli, India. International Journal of Earth Sciences Knowledge and Applications 2 (2), 48-63.

[33] Koerner, R.M., 1999. Designing with Geosynthetics. Prentice-Hall, Upper Saddle River, N.J.

[34] Li, J., Cameron, D.A., Ren, G., 2014. Case study and back analysis of a residential building damaged by expansive soils. Computers and Geotechnics 56, 89-99.

[35] Lin, B., Cerato, A., 2012. Investigation on soil-water characteristic curves of untreated and stabilized highly clayey expansive soils. Geotechnical and Geological Engineering 30 (4), 803-812.

[36] McKeen, R.G., 1988. Soil Characterization Using Suction Measurements", Proceedings, 25th Paving and Transportation Conference, University of New Mexico, Albuquerque, N.M.

[37] Mesri, G., Olson, R.E., 1971. Consolidation characteristics of montmorillonite, Geotechnique 21 (4), 341-352. 1971

[38] Miao, L., Wang, F., Cui, Y., Shi, S.B., 2012. Hydraulic characteristics, strength of cyclic wetting-drying and constitutive model of expansive soils. In: Proceedings of 4th International Conference on Problematic Soils, Wuhan, China, p. 303-322.

[39] Mitchell, J.K. 1993. Fundamentals of soil behavior. 2nd Ed., 1993. Wiley, New York.

[40] Nath, B.D., Molla, M.K.A., Sarkar, G., 2017. Study on Strength Behavior of Organic Soil Stabilized with Fly Ash. International Scholarly Research Notices 2017, 5786541.

[41] Nakase, A., Nakanodo, H., Kusakabe, O., 1978. Influence of soil type on pore pressure response to cyclic loading. In Proceeding of 5th Japan Earthquake Engineering Symposium, 593-600.

[42] Nelson, D.J., Miller, J.D., 1992. Expansive Soils: Problems and Practice in Foundation and Pavement Engineering", Wiley, New York.

[43] Okyay, U.S., Dias, D., 2010. Use of lime and cement treated soils as pile supported load transfer platform. Engineering Geology 114, 34-44.

[44] Oyedepo, O.J, Oluwajana, S.D., Akande, S.P., 2014. Investigation of Properties of Concrete Using Sawdust as Partial Replacement for Sand. Civil and Environmental Research 6 (2), 35-42.

[45] Ozer, M., Ulusay, R., Isik, N.S., 2011. Evaluation of damage to light structures erected on a fill material rich in expansive soil. Bulletin of Engineering Geology and the Environment 71 (7), 1-33.

[46] Petry, T.M., Little, D.N., 2002. Review of stabilization of clays and expansive soils in pavements and lightly loaded structures e history, practice, and future. Journal of Materials in Civil Engineering 14(6), 447-460.

[47] Phanikumar, B.R., 2009. Effect of lime and fly ash on swell, consolidation and shear strength characteristics of expansive clays: a comparative study. Journal Geomechanics and Geoengineering 4 (2), 175-181.

[48] Phanikumar, B.R., Amshumalini, C., Karthika, R., 2009. Volume Change Behaviour of Expansive Clay-Sand Blends. IGC 2009, Guntur, India.

[49] Poonia, J., Giustozzia, F., Roberta, D., Setungea, S., O'Donnellb, B., 2019. Durability of enzyme stabilized expansive soil in road pavements subjected to moisture degradation. Transportation Geotechnics 21, 100225.

[50] Rao, D.K., Anusha, M., Pranav, P.R.T., Venkatesh, G., 
2012. A laboratory study on the stabilization of marine clay using saw dust and lime. International Journal of Engineering Science and Advanced Technology 2 (4), 851-862.

[51] Selvakumar, S., Soundara, B., 2019. Swelling behavior of expansive soils with recycled geofoam granules column inclusion. Geotextiles and Geomembranes 47, 111.

[52] Shakoor, A., Cook, B.D., 1990. The effect of stone content, size and shape on engineering properties of compacted silty clay. Bulletin of the Association of Engineering Geologists 27, 245-253.

[53] Sharma, R.S., Phanikumar, B.R., 2005. Laboratory study of heave behavior of expansive clay reinforced with geopiles. Journal of Geotechnical and Geoenvironmental Engineering 131 (4), 512-520.

[54] Shelly, T.L., Daniel, D.E., 1993. Effect of gravel on hydraulic conductivity of compacted soil liners. Journal of Geotechnical Engineering 119, 54-68.

[55] Sheng, D., Gens, A., Fredlund, D.G., Sloan, S.W., 2008. Unsaturated soils: From constitutive modelling to numerical algorithms. Computer and Geotechnics 35 (6), 810-824.

[56] Shirazi, S.M., Kazama, H., Salman, F.A., Othman, F., Akib, S., 2010. Permeability and swelling characteristics of bentonite. International Journal of the Physical Sciences 5 (11), 1647-1659.

[57] Soltani-Jigheh, H., Jafari, K., 2012. Volume Change and Shear Behavior of Compacted Claysand/Gravel Mixtures. International Journal of Engineering and
Applied Sciences 4 (1), 52-66.

[58] Vallejo, L.E., Mawby, R., 2000. Void ratio Influence on the shear strength of granular material clay mixtures. Engineering Geology 58, 125-136.

[59] Viswanadham, B.V.S., Viswanadham, B.R., Mukherjee, R., 2009. Swelling behavior of a geofiber-reinforced expansive soil. Geotextiles and Geomembranes 27 (1), 73-76.

[60] Walsh, P.F, Cameron DA., 1997. The design of residential slabs and footings. Standards Australia, SAA HB28-1997.

[61] Yarbaş1, N., Kalkan, E., 2020a. Stabilization of Clayey Soils by Using the Organic Waste-Material. International Journal of Science and Engineering Applications 9 (11), 129-132.

[62] Yarbaş1, N., Kalkan E., 2020b. The Mechanical Performance of Clayey Soils Reinforced with Waste PET Fibers. International Journal of Earth Sciences Knowledge and Applications 2 (1) 19-26.

[63] Yarbaş1, N., Kalkan, E., 2020c. Investigation of Wet-Dry Cycle Effect on Swelling Behavior of Stabilized Expansive Soils. International Journal of Science and Engineering Applications 9 (12), 153-157.

[64] Yarbaş1, N., Kalkan, E., 2020d. Freeze-Thaw Resistance of Fine-Grained Soils Stabilized with Waste Material Mixtures. International Journal of Science and Engineering Applications 9 (12), 158-163.

[65] Yong, R.N., Ouhadi, V.R., 2007. Experimental study on instability of bases on natural and lime/cement-stabilized clayey soils. Applied Clay Science 35, 238-249. 